\title{
Topical Treatment for Scarring and Non-Scarring Alopecia: An Overview of the Current Evidence
}

\author{
Camila O Cardoso (iD) \\ Seila Tolentino' \\ Tais Gratieri' \\ Marcilio Cunha-Filho' \\ Renata FV Lopez $\mathbb{D}^{2}$ \\ Guilherme M Gelfuso (D) \\ 'Laboratory of Food, Drugs, and \\ Cosmetics (LTMAC), University of \\ Brasilia, Brasília, 70910-900, DF, Brazil; \\ ${ }^{2}$ School of Pharmaceutical Sciences of \\ Ribeirão Preto, University of São Paulo, \\ Ribeirão Preto, I4040-903, SP, Brazil
}

Correspondence: Guilherme M Gelfuso University of Brasília, Department of Pharmacy, Campus Universitário Darcy Ribeiro, Brasília, 70910-900, DF, Brazil

$\mathrm{Tel}+5561$ 3107-1990

Email gmgelfuso@unb.br

\begin{abstract}
Alopecia is a clinical condition related to hair loss that can significantly affect both male and female adults' quality of life. Despite the high market demand, only few drugs are currently approved for alopecia treatment. Topical formulations still bring drawbacks, such as scalp irritation with frequent use, and low drug absorption to the site of action, which limits the efficacy. The most recent research points out that different formulation technology could circumvent the aforementioned flaws. Such technology includes incorporation of drugs in rigid or deformable nanoparticles, strategies involving physical, energetical and mechanical techniques, such as iontophoresis, sonophoresis, microneedling, and the use of solid effervescent granules to be hydrated at the moment of application in the scalp. In this paper, the progress of current research on topical formulations dedicated to the treatment of alopecia is reviewed and discussed.
\end{abstract}

Keywords: alopecia, drug delivery, hair follicle, iontophoresis, nanoparticles, topical treatment

\section{Introduction}

Alopecia is a clinical condition characterized by hair loss from the scalp or any other part of the body ${ }^{1}$ caused by predefined genetic background, hormonal imbalance, infection, or idiopathic causes. ${ }^{2}$ It is one of the most prevalent dermatological disorders that affect the global population ${ }^{2}$ and can be subdivided into two main categories: scarring and non-scarring. ${ }^{1}$

In cases of scarring alopecia, the hair follicles are irreversibly destroyed, leading to permanent hair loss. This type of alopecia is less common (corresponds to only $5 \%$ of the cases) ${ }^{3}$ and presents several etiologies, as lymphocytic (discoid lupus erythematosus, lichen planopilaris, central centrifugal cicatricial alopecia, pseudopelade of Brocq), neutrophilic (folliculitis decalvans, dissecting folliculitis), and multiple causes (acne keloidalis). ${ }^{1,4,5}$

In non-scarring alopecia, the capillary cycle is altered, but the hair follicles are preserved, allowing hair regrowth. In this group, it is possible to distinguish certain conditions such as alopecia areata, tinea capitis, and trichotillomania characterized by unequal hair loss in certain specific regions, while diffuse hair loss can be caused by telogen or anagen effluvium. Androgenic alopecia, in turn, may be either diffuse or exhibit a specific pattern and can progress to complete baldness. ${ }^{1,4}$

Androgenic alopecia is the most common type of progressive hair loss, affecting $30-50 \%$ of men and approximately $30 \%$ of middle-aged women. ${ }^{6}$ It is characterized by the miniaturization of the hair follicles, ${ }^{7}$ as schematized in Figure 1 , as 


\section{PROGRESSION OF ANDROGENIC ALOPECIA}

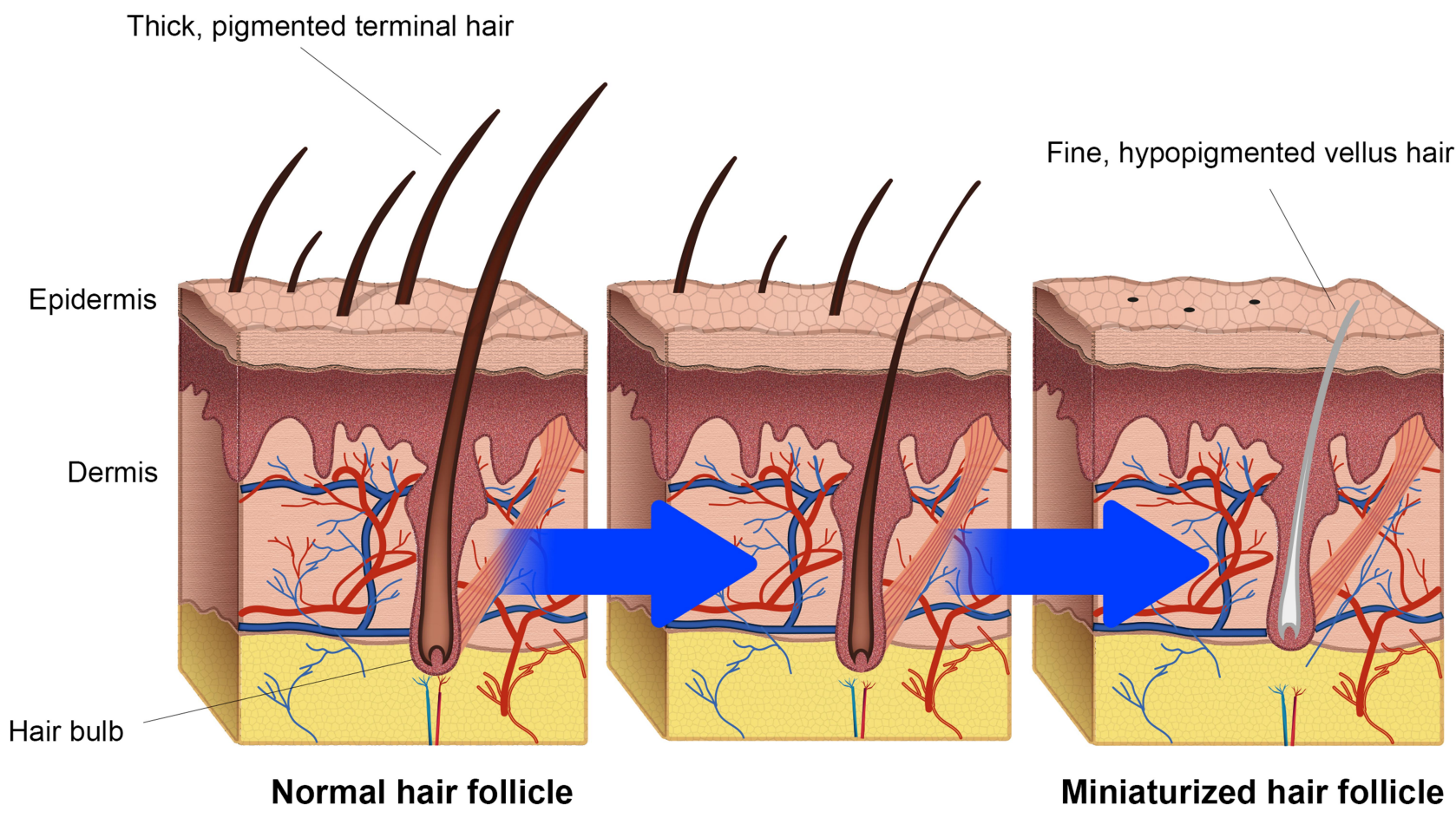

Figure I Progression of androgenic alopecia. The hair follicles are miniaturized due the increased concentration of dihydrotestosterone (DHT) in dermal papillae.

a consequence of an alteration in the hair growth cycle due to high concentrations of dihydrotestosterone (DHT), generated from the metabolization of the testosterone by the enzyme $5 \alpha$-reductase. ${ }^{8}$

The second most prevalent type of non-scarring alopecia is alopecia areata, ${ }^{9}$ which is associated with autoimmune problems of various origins. ${ }^{10}$

For scarring alopecia, the first-line therapy is applying a potent topical corticosteroid (class 3 or 4 ) on affected areas' borders, extending onto hair-bearing regions clinically unaffected. ${ }^{11}$ The topical and/or intralesional treatment may be a more attractive first-line agent to avoid sequelae of systemic corticosteroids, such as Cushing's syndrome, hyperglycemia, disturbances of blood pressure, and edemas. ${ }^{12}$ Considering the rarity of scarring alopecias, clinical studies to evaluate the proposed treatments' effectiveness are still very scarce. ${ }^{3}$

For each type of non-scarring alopecia, a different therapeutic regimen is proposed, ie, telogen effluvium and trichotillomania are treated by removing the precipitating cause; anagen effluvium has no effective pharmacologic treatment, although topical minoxidil may help during the regrowth process; alopecia areata can be self- limited, but topical corticosteroids are often effective; and androgenic alopecia can be treated with a variety of topical or oral medications, mainly containing the drugs minoxidil or finasteride. ${ }^{4}$

Data presented in Table 1 detail the treatments usually recommended for each type of alopecia.

Although the market for the treatment of alopecia is continually in high demand and generates billions of dollars annually worldwide, ${ }^{30}$ the therapeutic options approved by the United States Food and Drug Administration (FDA) are few and limited to finasteride for oral use in doses of $1 \mathrm{mg}$, minoxidil for topical use in doses of $2-5 \%$, in addition to topical corticosteroids. ${ }^{2}$

Minoxidil is a vasodilator that accelerates the secretion of growth factors for hair regeneration. ${ }^{31}$ After being approved by the FDA to treat androgenic alopecia, topical minoxidil has also been used as an off-label medication to treat several other types of alopecia, including alopecia areata, scarring alopecia, and anagen effluvium. ${ }^{32}$ Oral minoxidil, used as an antihypertensive agent, is not a therapeutic option due to side effects, which include sodium and fluid retention, acute pulmonary edema, and pulmonary hypertension, reflex tachycardia, and, less 
Table I Causes, Features, and Topical and Systemic Treatments of Scarring and Non-Scarring Alopecias

\begin{tabular}{|c|c|c|c|}
\hline \multicolumn{4}{|c|}{ Scarring Alopecia } \\
\hline Type & Cause and Features & Treatments & Reference \\
\hline $\begin{array}{l}\text { Discoid lupus } \\
\text { erythematosus }\end{array}$ & $\begin{array}{l}\text { A chronic and common form of cutaneous lupus, in } \\
\text { which the lesions typically occur on the scalp and other } \\
\text { sun-exposed areas characterized by follicular plugging, } \\
\text { atrophy, and hyperpigmentation. }\end{array}$ & $\begin{array}{l}\text { Topical corticosteroids; intralesional corticosteroid; } \\
\text { topical calcineurin inhibitors; antimalarial agents; oral } \\
\text { retinoids; and methotrexate. }\end{array}$ & {$[13,14]$} \\
\hline $\begin{array}{l}\text { Lichen } \\
\text { planopilaris }\end{array}$ & $\begin{array}{l}\text { Alopecia is characterized by multifocal and small } \\
\text { lesions caused by a chronic and uncommon } \\
\text { lymphocytic inflammation that leads to the selective } \\
\text { destruction of hair follicles. } \\
\text { Little Piccardi Lasseur syndrome, characterized by } \\
\text { keratotic papules on the trunk and extremities, non- } \\
\text { scarring alopecia of the axillary and pubic region, and } \\
\text { cicatricial alopecia of the scalp. }\end{array}$ & $\begin{array}{l}\text { Potent topical and intralesional corticosteroids; oral } \\
\text { corticosteroids; hydroxychloroquine; oral retinoids; } \\
\text { oral tetracyclines; cyclosporine; mycophenolate } \\
\text { mofetil; azathioprine with concurrent systemic } \\
\text { corticosteroids. }\end{array}$ & {$[15]$} \\
\hline $\begin{array}{l}\text { Central } \\
\text { centrifugal } \\
\text { cicatricial } \\
\text { alopecia }\end{array}$ & $\begin{array}{l}\text { A permanent hair loss in the crown region of the scalp } \\
\text { caused by inflammation and scarring. Predominantly } \\
\text { occurs in African descent women over } 30 \text { years old. }\end{array}$ & $\begin{array}{l}\text { Potent topical or intralesional corticosteroids; } \\
\text { systemic antibiotics; hydroxychloroquine; } \\
\text { mycophenolate mofetil. }\end{array}$ & {$[16,17]$} \\
\hline $\begin{array}{l}\text { Pseudopelade } \\
\text { of Brocq }\end{array}$ & $\begin{array}{l}\text { An idiopathic and slowly progressive form of cicatricial } \\
\text { alopecia, which usually affects middle-aged Caucasian } \\
\text { women. This condition is characterized by multiple } \\
\text { small flash-toned alopecic areas with irregular borders } \\
\text { without any signs of hyperkeratosis or inflammation. }\end{array}$ & $\begin{array}{l}\text { Potent topical and intralesional corticosteroids; topical } \\
\text { minoxidil; hydroxychloroquine; oral corticosteroids; } \\
\text { isotretinoin; mycophenolate mofetil. }\end{array}$ & {$[18,19]$} \\
\hline $\begin{array}{l}\text { Folliculitis } \\
\text { decalvans }\end{array}$ & $\begin{array}{l}\text { Uncommon scalp disease possibly triggered by } \\
\text { Staphylococcus aureus and alteration of the patient's } \\
\text { local immune response. } \\
\text { Erythematous patch, follicular pustules or papules, and } \\
\text { follicular hyperkeratosis involving the vertex and the } \\
\text { scalp's occipital area are the clinical sign of this } \\
\text { condition. }\end{array}$ & $\begin{array}{l}\text { Combined topical and oral antibiotics; topical or } \\
\text { intralesional corticosteroids; isotretinoin; topical } \\
\text { antimicrobial or antiseptic therapy. }\end{array}$ & {$[11,20]$} \\
\hline $\begin{array}{l}\text { Dissecting } \\
\text { folliculitis }\end{array}$ & $\begin{array}{l}\text { Rare alopecia characterized by a deep follicular } \\
\text { occlusion, followed by follicular rupture and a deep } \\
\text { inflammation of the hair follicle's bulb. }\end{array}$ & $\begin{array}{l}\text { Isotretinoin orally; topical or intralesional } \\
\text { corticosteroids; oral or topical antibiotics; systemic } \\
\text { corticosteroids; dapsone; and laser epilation. }\end{array}$ & {$[21,22]$} \\
\hline Acne keloidalis & $\begin{array}{l}\text { A chronic form of scarring folliculitis that affects mostly } \\
\text { African descent men. The exact cause remains } \\
\text { unknown. The inciting agents are multifactorial such as } \\
\text { androgens, inflammation, infection, trauma, genetics, } \\
\text { and growing hair. This condition is characterized by } \\
\text { papules, pustules, and, sometimes, tumorous masses in } \\
\text { the scalp's nuchal or occipital regions. }\end{array}$ & $\begin{array}{l}\text { Potent topical or intralesional corticosteroids; oral } \\
\text { antibiotics; and surgical excision. }\end{array}$ & [23] \\
\hline \multicolumn{4}{|c|}{ Non-Scarring Alopecia } \\
\hline Type & Cause and Features & Treatments & Reference \\
\hline Alopecia areata & $\begin{array}{l}\text { Specific autoimmune disease of the hair follicle with } \\
\text { a genetic basis. Acute patchy hair loss is frequently } \\
\text { reported. }\end{array}$ & $\begin{array}{l}\text { Intralesional corticosteroids; topical corticosteroids; } \\
\text { and minoxidil. }\end{array}$ & {$[10,24]$} \\
\hline
\end{tabular}


Table I (Continued).

\begin{tabular}{|c|c|c|c|}
\hline \multicolumn{4}{|c|}{ Scarring Alopecia } \\
\hline Type & Cause and Features & Treatments & Reference \\
\hline Tinea capitis & $\begin{array}{l}\text { Alopecia caused by dermatophyte fungal infection on } \\
\text { the scalp hair with predominance in children. Scaling } \\
\text { with little hair loss to extensive alopecia, together with } \\
\text { large inflammatory and pustular plaques. }\end{array}$ & $\begin{array}{l}\text { Oral terbinafine, itraconazole, fluconazole, or } \\
\text { griseofulvin. } \\
\text { Topical antifungal as a complementary therapy to oral } \\
\text { therapy. }\end{array}$ & [25] \\
\hline Trichotillomania & $\begin{array}{l}\text { Hair-pulling disorder producing hair loss and functional } \\
\text { impairment. }\end{array}$ & $\begin{array}{l}\text { Optimal treatment is unknown; selective serotonin } \\
\text { reuptake inhibitors; behavioral therapy. }\end{array}$ & [26] \\
\hline $\begin{array}{l}\text { Telogen } \\
\text { effluvium }\end{array}$ & $\begin{array}{l}\text { Excessive shedding of hair, caused by an abnormality in } \\
\text { the normal hair cycle, triggered by several factors such } \\
\text { as drugs, physiological and emotional stress, and } \\
\text { medical conditions. }\end{array}$ & Remove the underlying cause; topical corticosteroids. & [27] \\
\hline $\begin{array}{l}\text { Anagen } \\
\text { effluvium }\end{array}$ & $\begin{array}{l}\text { Chemotherapy-induced alopecia characterized by } \\
\text { a diffuse hair loss days to weeks after exposure to } \\
\text { a chemotherapeutic agent. }\end{array}$ & $\begin{array}{l}\text { No pharmacologic intervention has been proven } \\
\text { effective, although minoxidil may speed up the } \\
\text { regrowth period. }\end{array}$ & [28] \\
\hline $\begin{array}{l}\text { Androgenic } \\
\text { alopecia }\end{array}$ & $\begin{array}{l}\text { The most common type of progressive hair loss with } \\
\text { genetic causes. } \\
\text { Men: typically involve frontal and vertex areas while } \\
\text { preserving the occipital region. } \\
\text { Women: diffuse hair thinning of the vertex with sparing } \\
\text { of the frontal hairline. }\end{array}$ & $\begin{array}{l}\text { Men: topical minoxidil ( } 2 \% \text { or } 5 \% \text { solution); oral } \\
\text { finasteride. } \\
\text { Women: topical minoxidil (I-5\% solution). }\end{array}$ & {$[6,29]$} \\
\hline
\end{tabular}

commonly, EKG changes, pericardial effusion, and congestive heart failure. ${ }^{33}$

Finasteride blocks the enzyme $5 \alpha$-reductase, responsible for converting testosterone to DHT, which results in a significant reduction in DHT concentration. Oral administration of finasteride can cause systemic side effects, including mood disturbance, gynecomastia, decreased libido, erectile dysfunction, and ejaculation disorder. ${ }^{34}$ In this regard, a topical route could be a better option to target this drug to the site of action, minimizing side effects, although the physicochemical characteristics of this drug, such as its low aqueous solubility and reduced stability, hinder its topical skin delivery.

Regarding the corticosteroids, some major drawbacks of chronic, systemic treatment are the numerous adverse reactions, affecting nearly every organ system and metabolic process in the body. Among the systemic side effects are hypothalamic-pituitary-adrenal axis suppression, osteoporosis, immunosuppression, muscle wasting, and physical appearance changes (moon facies, buffalo hump, and central trunk obesity). ${ }^{12}$ Long-term treatment with topical corticosteroids may thus be preferred to avoid the aforementioned systemic adverse effects.
In this scenario, this paper proposes to establish the main problems related to topical formulations for the treatment of alopecia that result in low therapeutic effect, and to discuss the technological strategies that have been proposed over the last ten years in order to overcome these obstacles.

\section{Challenges of Current Topical Treatments for Alopecia}

Current topical pharmacotherapy for alopecia includes prescription of formulations such as lotions, solutions, and foam, ${ }^{2}$ whose low viscosity and little or no fat content facilitates spreading both in areas of absolute baldness and in areas where hair growth is only scarce. ${ }^{35,36}$ As mentioned before, the main drugs contained in these formulations are minoxidil, which was the first drug approved by the FDA for topical use ${ }^{37}$; finasteride and its more potent derivative dutasteride, which despite the approval being for oral use, several studies already propose their topical administration (as listed in Table 2); and corticosteroids. ${ }^{38}$ Several complementary adjuvants, including natural actives and cosmetics compounds, which reduce skin oiliness or improve blood circulation at the application site have been added to these formulations. ${ }^{34,39,40}$ 
Table 2 Summary of the Encouraging Outcomes from Cutaneous Permeation Studies with Nanoparticles Carried with Drugs Indicated for Alopecia

\begin{tabular}{|c|c|c|c|c|c|}
\hline Drug & $\begin{array}{l}\text { Types of } \\
\text { Nanoparticles }\end{array}$ & $\begin{array}{l}\text { Particle } \\
\text { Size (nm) }\end{array}$ & Test Model & Outcome & Reference \\
\hline Cyclosporin A & PLA nanoparticles & 150 & $\begin{array}{l}\text { Abdominal porcine } \\
\text { skin }\end{array}$ & $\begin{array}{l}\text { Cyclosporin A-loaded PLA nanoparticles were } \\
\text { accumulated inside the hair follicles along the } \\
\text { entire follicular duct. On the other hand, no } \\
\text { staining was detected in skin sections treated } \\
\text { with Cyclosporin A-containing non-particulate } \\
\text { drug solution (control). }\end{array}$ & [55] \\
\hline $\begin{array}{l}\text { Clobetasol } \\
\text { propionate }\end{array}$ & $\begin{array}{l}\text { Polymeric } \\
\text { nanospheres, } \\
\text { nanocapsules, and } \\
\text { lipid-core } \\
\text { nanocapsules }\end{array}$ & $100-260$ & $\begin{array}{l}\text { Human heat- } \\
\text { separated } \\
\text { epidermis (HHSE) }\end{array}$ & $\begin{array}{l}\text { All nanocarriers tested reduced the undesired } \\
\text { transdermal permeability in comparison to the } \\
\text { application of the free drug. }\end{array}$ & [47] \\
\hline $\begin{array}{l}\text { Clobetasol } \\
\text { propionate }\end{array}$ & $\begin{array}{l}\text { Nanostructured lipid } \\
\text { carriers }\end{array}$ & 180 & $\begin{array}{l}\text { Skin from porcine } \\
\text { ears }\end{array}$ & $\begin{array}{l}\text { Nanoparticles released the drug in a sustained } \\
\text { fashion for more than } 3 \text { days and increased } \\
\text { passively in about } 40 \text { times the clobetasol } \\
\text { follicular uptake, compared to the commercial } \\
\text { cream. }\end{array}$ & [56] \\
\hline Diphencyprone & $\begin{array}{l}\text { Nanostructured lipid } \\
\text { carriers }\end{array}$ & $208-265$ & $\begin{array}{l}\text { Nude and hairy } \\
\text { mouse dorsal skin }\end{array}$ & $\begin{array}{l}\text { A more regular absorption of diphencyprone was } \\
\text { achieved by applying nanostructured lipid carriers } \\
\text { compared to the control. }\end{array}$ & [57] \\
\hline $\begin{array}{l}\text { Diphencyprone } \\
\text { and Minoxidil }\end{array}$ & $\begin{array}{l}\text { Nanostructured lipid } \\
\text { carriers and } \\
\text { nanoemulsions }\end{array}$ & $\begin{array}{l}177 \text { and } \\
194\end{array}$ & $\begin{array}{l}\text { Female nude mice } \\
\text { (ICR-Foxn Inu) }\end{array}$ & $\begin{array}{l}\text { Follicular uptake by squarticles was } 2 \text { - and } 7 \text {-fold } \\
\text { higher for diphencyprone and minoxidil, } \\
\text { respectively, compared to the free drug controls. }\end{array}$ & [58] \\
\hline Dutasteride & $\begin{array}{l}\text { Poly-( } \varepsilon \text {-caprolactone) } \\
\text {-lipid-core, coated } \\
\text { with chitosan } \\
\text { nanoparticles }\end{array}$ & 199 & $\begin{array}{l}\text { Skin from porcine } \\
\text { ears }\end{array}$ & $\begin{array}{l}\text { Both coated and non-coated nanoparticles } \\
\text { targeted the hair follicles compared to a drug } \\
\text { solution, which is appropriate aiming the topical } \\
\text { treatment of alopecia }\end{array}$ & [59] \\
\hline Finasteride & $\begin{array}{l}\text { Liquid crystalline } \\
\text { formulation }\end{array}$ & $154-170$ & $\begin{array}{l}\text { Dorsal skin of male } \\
\text { hairless mice }\end{array}$ & $\begin{array}{l}\text { Liquid crystalline formulation increased the drug } \\
\text { penetration in the skin compared with control. }\end{array}$ & [34] \\
\hline Finasteride & PLA nanoparticles & 300 & $\begin{array}{l}\text { PDMS membrane } \\
\text { as a simplified } \\
\text { model of human } \\
\text { epidermis }\end{array}$ & $\begin{array}{l}\text { The nanoparticles prolonged the time finasteride } \\
\text { remained on the skin. }\end{array}$ & [60] \\
\hline $\begin{array}{l}\text { Finasteride or } \\
\text { Dutasteride }\end{array}$ & $\begin{array}{l}\text { Metallic nanoparticles } \\
\text { (iron oxide) }\end{array}$ & 123 & $\begin{array}{l}\text { Skin from porcine } \\
\text { ears }\end{array}$ & $\begin{array}{l}\text { Metallic nanoparticles exhibited a higher skin drug } \\
\text { penetration compared to each respective control } \\
\text { solution. }\end{array}$ & [46] \\
\hline Flutamide & $\begin{array}{l}\text { Solid lipid } \\
\text { nanoparticles }\end{array}$ & 198 & $\begin{array}{l}\text { Male Wistar rats } \\
\text { (in vitro) and young } \\
\text { male hamsters } \\
\text { (in vivo) }\end{array}$ & $\begin{array}{l}\text { In vitro: flutamide-loaded solid lipid nanoparticles } \\
\text { formulation exhibited significantly higher } \\
\text { deposition of Flutamide in the skin }(62.95 \pm 6.2 \%) \\
\text { than the hydroalcoholic solution ( } 35.83 \pm 4.1 \%) \text {. } \\
\text { In vivo: flutamide-loaded solid lipid nanoparticles } \\
\text { increased the number of hair follicles more than } \\
\text { the solution when applied to the skin. }\end{array}$ & [6I] \\
\hline
\end{tabular}

(Continued) 
Table 2 (Continued).

\begin{tabular}{|c|c|c|c|c|c|}
\hline Drug & $\begin{array}{l}\text { Types of } \\
\text { Nanoparticles }\end{array}$ & $\begin{array}{l}\text { Particle } \\
\text { Size (nm) }\end{array}$ & Test Model & Outcome & Reference \\
\hline Latanoprost & $\begin{array}{l}\text { Poly- } \varepsilon \text {-caprolactone } \\
\text { nanocapsules }\end{array}$ & 198 & $\begin{array}{l}\text { Skin from porcine } \\
\text { ears }\end{array}$ & $\begin{array}{l}\text { The nanocapsules improved latanoprost } \\
\text { accumulation into the hair follicles, delivering } 30 \% \\
\text { more drug to these skin structures relative to the } \\
\text { control solution. }\end{array}$ & [62] \\
\hline Minoxidil & $\begin{array}{l}\text { Solid lipid } \\
\text { nanoparticles }\end{array}$ & 190 & $\begin{array}{l}\text { Skin from porcine } \\
\text { ears }\end{array}$ & $\begin{array}{l}\text { Penetration experiments with porcine skin } \\
\text { showed that the solid lipid nanoparticles } \\
\text { suspension penetration into skin layers was } \\
\text { statistically non-different to commercial products } \\
\text { for formulation applied in excess. }\end{array}$ & [63] \\
\hline Minoxidil & $\begin{array}{l}\text { Nanostructured lipid } \\
\text { carriers }\end{array}$ & 281 & $\begin{array}{l}\text { Abdominal skin of } \\
\text { male Sprague } \\
\text { Dawley rats }\end{array}$ & $\begin{array}{l}\text { Compared to the traditional formulation for the } \\
\text { topical delivery of minoxidil, the nanostructured } \\
\text { lipid carriers showed the highest skin retention. }\end{array}$ & [42] \\
\hline Minoxidil & Niosomes & $214-1368$ & $\begin{array}{l}\text { Fresh hairless } \\
\text { mouse skin }\end{array}$ & $\begin{array}{l}\text { Smaller niosomes }(214-252 \mathrm{~nm}) \text { achieved } \\
\text { a higher minoxidil skin penetration than the larger } \\
\text { ones }(1160-1240 \mathrm{~nm}) .\end{array}$ & [64] \\
\hline Minoxidil & $\begin{array}{l}\text { Chitosan } \\
\text { nanoparticles }\end{array}$ & 235 & $\begin{array}{l}\text { Skin from porcine } \\
\text { ears }\end{array}$ & $\begin{array}{l}\text { Nanoparticles application resulted in a two-fold } \\
\text { minoxidil increase into hair follicles after } 6 \\
\text { h compared to the control solution. }\end{array}$ & [50] \\
\hline Minoxidil & $\begin{array}{l}\text { PLGA and hyaluronic } \\
\text { acid-PLGA } \\
\text { nanoparticles }\end{array}$ & $\begin{array}{l}\text { PLGA: } 159 \\
\text { HA-PLGA: } \\
243\end{array}$ & Rat skin & $\begin{array}{l}\text { HA-PLGA nanoparticles were more permeable } \\
\text { than PLGA nanoparticles and more efficient in } \\
\text { transdermal delivery. }\end{array}$ & [31] \\
\hline Minoxidil & $\begin{array}{l}\text { Polymeric } \\
\text { nanoparticles }\end{array}$ & $90-300$ & $\begin{array}{l}\text { Male 7-week-old } \\
\text { C57BL/6 mice }\end{array}$ & $\begin{array}{l}\text { The minoxidil content in the hair bulbs of mice } \\
\text { treated with nanoparticles was } 6.0 \text { - and I.8-fold } \\
\text { higher than in mice treated with the formulation } \\
\text { based on minoxidil powder and the commercially } \\
\text { available minoxidil formulation, respectively. }\end{array}$ & [65] \\
\hline Minoxidil & $\begin{array}{l}\text { Metallic nanoparticles } \\
\text { (iron oxide) }\end{array}$ & $150-200$ & Mice C57BL/6 & $\begin{array}{l}\text { The mice's hair density exhibited an } 800 \% \\
\text { improvement after being treated by microneedle, } \\
\text { followed by an external magnetic field, compared } \\
\text { to the mice without any treatments. }\end{array}$ & [66] \\
\hline $\begin{array}{l}\text { Minoxidil and } \\
\text { Diphencyprone }\end{array}$ & $\begin{array}{l}\text { Liposomes and } \\
\text { niosomes }\end{array}$ & $\begin{array}{l}200-300 \\
\text { and } \\
750-3200\end{array}$ & $\begin{array}{l}\text { Fresh human skin } \\
\text { obtained fromm } \\
\text { abdominoplasty }\end{array}$ & $\begin{array}{l}\text { Liposome formulations increased drugs skin } \\
\text { penetration compared to a propylene glycol- } \\
\text { water-ethanol solution. }\end{array}$ & [67] \\
\hline $\begin{array}{l}\text { Minoxidil and } \\
\text { Finasteride }\end{array}$ & $\begin{array}{l}\text { Nanostructured lipid } \\
\text { carriers }\end{array}$ & 200 & Porcine ear skin & $\begin{array}{l}\text { Nanostructured lipid carriers loaded with } \\
\text { minoxidil and finasteride had low penetration } \\
\text { levels through pig ear skin under physiological } \\
\text { conditions, which would avoid a toxic, systemic } \\
\text { exposure. }\end{array}$ & [68] \\
\hline Quercetin & $\begin{array}{l}\text { PLGA and DPPC- } \\
\text { PLGA nanoparticles }\end{array}$ & 339 & $\begin{array}{l}\text { Male Sprague- } \\
\text { Dawley rats } \\
\text { (in vivo) }\end{array}$ & $\begin{array}{l}\text { Hybrid nanoparticles improved the hair regrowth } \\
\text { potential of quercetin, and the accumulation of } \\
\text { nanoparticles at hair follicles end region inhibit } \\
\text { hair follicles cells apoptosis. }\end{array}$ & [69] \\
\hline
\end{tabular}

(Continued) 
Table 2 (Continued).

\begin{tabular}{|l|l|l|l|l|l|}
\hline Drug & $\begin{array}{l}\text { Types of } \\
\text { Nanoparticles }\end{array}$ & $\begin{array}{l}\text { Particle } \\
\text { Size }(\mathbf{n m})\end{array}$ & Test Model & Outcome & Reference \\
\hline Spironolactone & $\begin{array}{l}\text { Nanostructured lipid } \\
\text { carriers }\end{array}$ & $216-834$ & $\begin{array}{l}\text { Newly born albino } \\
\text { mice }\end{array}$ & $\begin{array}{l}\text { Fluorine-labeled nanostructured lipid carriers } \\
\text { accumulated preferentially at the follicular region } \\
\text { compared to the non-follicular region, indicating } \\
\text { that the follicular pathway was the main } \\
\text { penetration pathway of such nanoparticles }\end{array}$ & [70] \\
\hline
\end{tabular}

Topical minoxidil has the disadvantage of limited efficiency, ${ }^{31}$ as it depends on sulfotransferase enzymes in the hair follicle's outer root sheath to be converted into its active form - minoxidil sulfate. ${ }^{41}$ Commercial formulations of this drug are currently solutions in alcohol or propylene glycol due to its poor water solubility, which may produce skin irritation such as scalp dryness, burning, redness, and allergic contact dermatitis, which interfere in the effectiveness of the therapy. ${ }^{42}$ Furthermore, formulations with ethanol as solvent are prone to promote the crystallization of the drug at the application site due to the solvent's rapid evaporation, preventing its penetration into the skin. ${ }^{43}$ In this sense, even the scalp condition prior to the formulation application, ie, whether the scalp is wet or dry, can affect formulations efficiency. ${ }^{44}$ Besides, there are several undesirable formulations' characteristics that limit patient compliance, from the unpleasant smell to the "hard" aspect they leave the hair. Patients who have dyed hair also face speeded discoloration issues.

To overcome oral finasteride or dutasteride side effects, topical formulations of these drugs have been proposed as a new therapeutic option. ${ }^{38}$ The aim is to create topical formulations with high skin penetration and deposition into the hair bulb and low systemic absorption; however, finasteride and dutasteride are highly lipophilic drugs, which hinders both their incorporation in dermatologically accepted vehicles and their deeper penetration into the skin. $^{45,46}$

Topically applied glucocorticoids are highly related to the occurrence of local adverse effects due to high dermal absorption. One of the most challenging local side effects is cutaneous atrophy, characterized by a reduction in the viable epidermis and stratum corneum thickness, alterations in the arrangement of collagen and elastin fibers, decreased number of keratinocytes, elimination of fatty tissue, and loss of mast cells. ${ }^{47}$

The scenario presented above highlights some of the challenges that have been considered in recent studies for the development of novel dermatological formulations for the treatment of alopecia. We further discuss the advances in topical formulations to manage alopecia with the application of nanostructured drug delivery systems along with other technological alternatives, such as the use of iontophoresis, sonophoresis, microneedles, and effervescent solid formulation.

\section{Nanoparticles-Based Formulations}

A large number of nanoparticles, obtained from different materials, such as degradable polymers and biopolymers, lipids and phospholipids, and even metals, have been proposed to enable the topical treatment of alopecia.

In general, these nanoparticles can reduce the irritant potential of drug molecules and control their release. Also, the colloids obtained with the aqueous dispersion of the nanostructures eliminate or at least considerably reduce the use of organic solvents or oil in the formulations, impacting both the reduction of toxicity and skin irritation, as well as the sensory acceptability of the product. Still, several studies have shown that topically applied nanoparticles tend to accumulate into hair follicles, ${ }^{48-52}$ which is a desirable outcome as this is the therapeutic target for alopecia. In fact, the follicle infundibulum increases the surface area and breaks the epidermal barrier towards the lower parts of the follicles, serving as an efficient reservoir for drug skin penetration and creating the possibility of sustained drug administration (Figure 2). ${ }^{53}$

Efficient drug delivery through such nanostructured systems depends on the interaction of the nanoparticles with the skin. In this context, the modulation of their physicochemical properties, such as the particle size, the surface charge, the material they are made of, and the method of application, are decisive for a successful therapy. ${ }^{54}$

The outcomes of skin permeation studies with nanoparticles loaded with drugs indicated for alopecia are summarized in Table 2. 


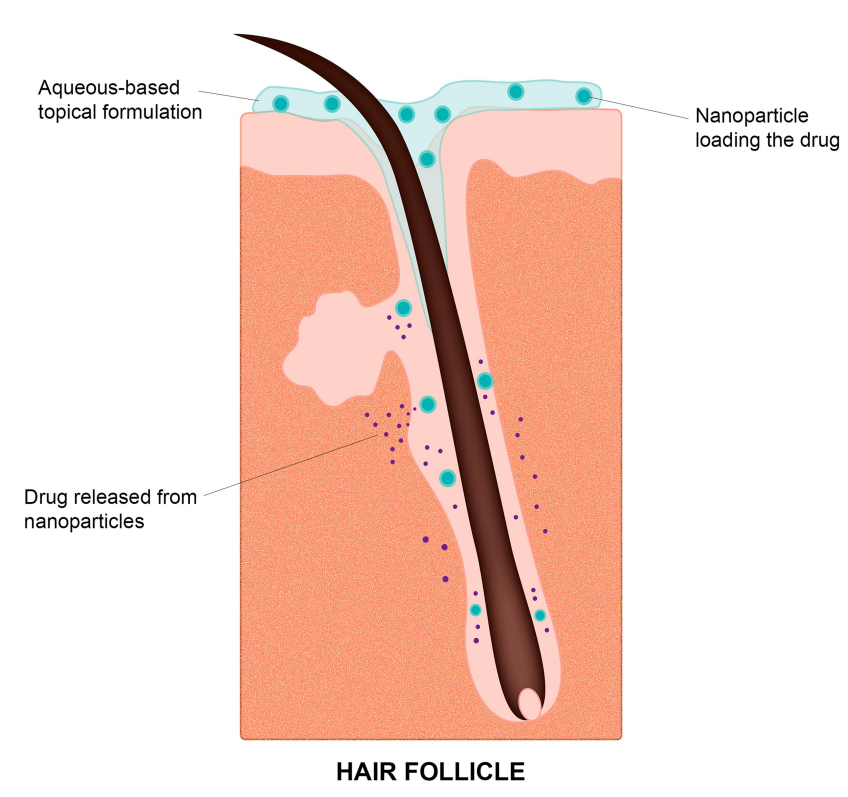

Figure 2 Scheme of the proposed mechanism for targeted drug delivery to the hair follicles provided by topical application of a nanoparticulate formulation.

The particle size has demonstrated a prominent effect on nanoparticle penetration depth, enabling differentiated targeting from the follicular structures. ${ }^{52,71}$ The material with which the nanoparticles are produced does not have as much impact on the deposition of the nanostructure itself, ${ }^{54,72,73}$ but it does affect the time they will have to interact with the skin surface and hair follicles, thinking about systems that are more quickly biodegraded (such as some biodegradable polymers and lipids) and the nature of the interaction with, for example, the sebaceous content of hair follicles. ${ }^{74}$

A study compared the follicular deposition of three types of nanoparticles with the same size range (polymer nanospheres of $128 \mathrm{~nm}$, polymer nanocapsules of $257 \mathrm{~nm}$, and lipid core nanocapsules of $197 \mathrm{~nm}$ ) and found a greater follicular uptake of the lipid core nanocapsules, which were more flexible than the others, and whose lipid content interacts better with the sebum content of the hair follicles. ${ }^{8,47}$

Further, we specify and discuss different types of nanoparticles that have already been developed to benefit the topical treatment of alopecia, taking into account whether they are deformable nanoparticles such as lipid nanoparticles and vesicles or rigid systems, such as polymeric or metallic ones.

\section{Deformable Nanoparticles}

This nanoparticle category is constituted by solid lipid nanoparticles, nanostructured lipid carriers, liposomes, and other lipid vesicles. These systems' elastic characteristics are directly related to the fluidity of the lipid or phospholipid bilayer that compose them. The presence of lipids in these nanoparticles also facilitates the interaction with the sebum present in the hair follicle ducts due to the similarity of structures and lipophilicity, ${ }^{53}$ in addition to ensuring high biocompatibility with the skin.

Lipid nanoparticles, such as solid lipid nanoparticles and nanostructured lipid carriers, easily form colloidal dispersions in water, which is well stabilized by emulsifiers. The lipid components are biocompatible and biodegradable, presenting high tolerability. These nanoparticles bring together favorable characteristics for topical application, such as controlled release and drug targeting, improved physical stability, and versatility as it allows incorporating lipophilic and hydrophilic drugs. Regarding the production, such nanoparticles are obtained avoiding the use of solvent, following simple and scalable manufacturing processes, such as high-pressure homogenization, microemulsion, or ultrasound techniques. They also have occlusive properties that can increase the skin's water content, favoring the penetration of the drug and interaction with skin lipids, as well as protecting against chemical degradation. ${ }^{53,75,76}$

A suspension of solid lipid nanoparticles entrapping minoxidil made of semi-synthetic triglycerides stabilized with a mixture of polysorbate and sorbitan oleate had its performance compared with commercial drug solutions in terms of skin penetration and cutaneous corrosion. The drug follicular penetration from the solid lipid nanoparticles was comparable to that of the commercial products, but the nanoparticles proved not to be irritating like the commercial products, which is an important feature related to treatment adherence. ${ }^{63}$ An association of minoxidil with finasteride was also entrapped into lipid nanoparticles to target the dermis and hair follicles. The nanoparticles prolonged drugs' release compared to free drugs, restricting the systemic exposure and concentrating the minoxidil and finasteride delivery to the follicular bulbs. ${ }^{55}$

Nanostructured lipid carriers containing clobetasol were also developed for follicular targeting, keeping in mind the topical treatment of alopecia areata or other scarring alopecias. The aim was to control the drug release while targeting and increasing the corticosteroid's penetration to the hair follicles, avoiding their local side effects such as skin atrophy, pruritus, folliculitis, and telangiectasia. Such nanoparticles could release the drug in a sustained manner for more than 3 days and increased 
clobetasol follicular uptake by 40 times compared to commercial cream. Additionally, a manual massage increased more than twice the amount of clobetasol accumulated into the hair follicles. ${ }^{56}$ Indeed, the motion induced the nanosystem's deposition inside the hair follicles with maximal velocity, which stimulates the entrapped drug deposition in these structures, as revealed before. ${ }^{77}$

Deformable nanoparticles have also been studied to topically deliver other drugs with undesirable systemic side effects, such as flutamide. This potent nonsteroidal anti-androgen inhibits the uptake and binding of androgens to receptors, ${ }^{78}$ but its systemic administration causes several side effects, such as reducing libido, impairing spermatogenesis in men, and feminizing male fetuses in pregnant women. Hence, flutamide-loaded solid lipid nanoparticles deposited 1.75 -fold more drug to the skin than the drug's hydroalcoholic solution. ${ }^{61}$ As a consequence, significantly increased hair growth was observed in rats treated with the solid lipid nanoparticles compared to the control formulation. ${ }^{61}$

Nanostructured lipid carriers entrapping spironolactone, ${ }^{70}$ which is another antiandrogen drug that presents a series of systemic side effects, ${ }^{79}$ were confirmed inside the hair follicles after 8 hours of a topical application by laser scanning confocal microscopy. As the lipid nanocarriers were fluorescently labeled, a generalized distribution of fluorescence around hair follicles and hair axes was observed due to the accumulation of nanoparticles within this area, ${ }^{70}$ which benefits topical alopecia treatment.

Liposomes are vesicles composed mainly of one or more lipid bilayers consisting of mixtures of phosphatidylcholine with long or short hydrocarbon chains. A high morphological diversity of liposomes can be obtained by simply making adjustments on temperature, composition, and hydration in order to promote interaction between the vesicle and the sebum that fills the hair follicles orifice. $^{53,80}$ Transfersomes and niosomes, are variations of liposomes but composed of lipid surfactants with single-chain instead of the more-expensive phospholipids. These lipid surfactants act as edge activators to provide elasticity and deformability of the vesicle through a high radius of curvature. ${ }^{54}$

Nano-transfersomes (from 197 to $300 \mathrm{~nm}$ ) incorporated in gel formulations showed enhancement from 3.1- to 4.8 -fold of finasteride permeated across rat skin layers after 24 hours of treatment compared with a nonencapsulated finasteride gel formula. Microscopy studies comparing rhodamine-loaded transfersomes with a control in which free-rhodamine was dispersed in gel showed a higher concentration of the fluorescent marker on the skin when transfersomes were administered. ${ }^{81}$ Other study compared the skin delivery of minoxidil from liposomes and niosomes. Minoxidil transported by smaller liposomes (200-300 nm) penetrated more into epidermal and dermal layers of human skin after 8 hours than with larger niosome formulations (750-3200 nm) and the control solution (propylene glycol-water-ethanol). These results reaffirm the potential targeting to skin and skin appendages of liposomal carriers, which enhanced skin drug delivery. ${ }^{67}$

\section{Rigid Nanoparticles}

This category of nanoparticles is constituted by fewer flexible matrices, such as polymers and metals, and exhibits useful characteristics for topical application, as greater stability along with a more substantial control of drug release in comparison with the deformable nanoparticles. Such controlled drug release can still be modulated to respond to different conditions such as $\mathrm{pH}$, enzymatic degradation of the polymer, or temperature, depending on the polymeric material. ${ }^{82}$ In turn, metallic nanoparticles are less costly and easier to obtain and scale-up, in addition to allowing excellent control of size, distribution, shape, and stability. ${ }^{46}$

\section{Polymeric Nanoparticles}

Polymers like poly(lactic-co-glycolic) (PLGA), ${ }^{31,60,69}$ poly- $\varepsilon$-caprolactone, ${ }^{62}$ poly(D,L-lactide) $(\mathrm{PLA})^{55}$ and $\operatorname{chitosan}^{50}$ have been often used as matrices to produce nanoparticles that encapsulate drugs for the topical treatment of alopecia, resulting in high skin biocompatibility approaches. Also, nanoparticles composed of these biodegradable polymers have shown to target the hair follicles upon topical application, ensuring controlled drug release once deposited into the follicular casts. A classical study used confocal laser scanning microscopy to reveal that non-biodegradable fluorescent polystyrene nanoparticles (diameters of 20 and $200 \mathrm{~nm}$ ) preferably accumulated in the follicular openings when applied to porcine skin. ${ }^{83}$

Polymeric nanoparticles loading minoxidil have been the most studied system for the topical treatment of alopecia. The objective is always to search for a system that reduces several inconveniences of long-term application of minoxidil conventional solutions, such as the irritation that these formulations and the drug itself cause to the skin, and to eliminate the use of organic solvents in the 
formulation that is commonly used to solubilize the drug, which generating a "dandruff" look on the scalp when it evaporates. Obviously, the studies also seek to concentrate the drug delivery to the hair follicles, with subsequent controlled drug release at this site. In such context, chitosan nanoparticles of around $235 \mathrm{~nm}$ application on skin showed a two-fold minoxidil increase into hair follicles after $6 \mathrm{~h}$ in comparison to the control solution; ${ }^{50}$ PLGA grafted hyaluronate nanoparticles delivered a sufficient amount of minoxidil into the hair follicles to stimulating hair growth in bulb cells without causing cytotoxicity; ${ }^{31}$ and nanoparticles prepared with methylcellulose, $p$-hydroxyalkylbenzoates, and mannitol demonstrated hair-growth effects in C57BL/6 mice, in which minoxidil content in the hair bulbs when the animals were treated with minoxidil nanoparticles was up to 6-fold higher than that in mice treated with the formulation based on minoxidil powder. ${ }^{65}$

Another proposal already studied was PLGA nanoparticles to entrap an association of quercetin and finasteride. ${ }^{60,69}$ The $300 \mathrm{~nm}$-nanoparticles demonstrated high accumulation into the hair follicles, reinforcing the targeting and depot effect of the nanoparticles, and inhibited hair follicle cells apoptosis, ${ }^{60,69}$ demonstrating their effectiveness in controlling alopecia.

Polymeric nanocapsules containing latanoprost were also proposed for the topical treatment of alopecia. Recent clinical studies pointed that these prostaglandin F2 alpha analogs, formerly indicated for topical treatment of glaucoma, significantly increased the capillary density of bald patients, suggesting a potential for treating alopecia. Poly- $\varepsilon$-caprolactone nanocapsule of $198 \mathrm{~nm}$ efficiently encapsulated more than $95 \%$ of this lipophilic drug and, despite not controlling drug release, stimulated 1.3-fold the latanoprost uptake into the hair follicles, as compared to the free-drug in a surfactant control solution. A manual massage of these nanocapsules upon skin application also increased latanoprost accumulation into the hair follicles by approximately 2 times. $^{62}$ This same polymer has already been used to prepare nanocapsules of dutasteride, ${ }^{59}$ another highly lipophilic drug that acts as a selective and competitive inhibitor of both type-1 and type- 2 isoenzymes of 5 - $\alpha$-reductase. ${ }^{84}$ The nanocapsules were coated with chitosan to provide a positive surface charge to the nanosystem. Chitosan coating increased the nanocapsule size from $199.0 \pm 0.5 \mathrm{~nm}$ to $224.9 \pm 3.4 \mathrm{~nm}$ and reduced the rate of drug release. The absence of chitosan coating, alternatively, favored the deposition of the dutasteride into the hair follicles $\left(1.6 \pm 0.3 \mu \mathrm{g} / \mathrm{cm}^{2}\right.$ versus $0.7 \pm 0.3 \mu \mathrm{g} / \mathrm{cm}^{2}$ ), probably due to the delay in drug release caused by the chitosan coating. Additionally, a mechanical massage upon skin application increased the amount of drug accumulated by about 5 times. ${ }^{59}$

The systemic adverse reactions of cyclosporine, an immunosuppressive drug used against various autoimmune skin diseases (eg, areata alopecia and other scarring baldness), have also been proposed to be circumvented by topical application of PLA nanoparticles loading this drug. In this way, cyclosporine, which presented a limited skin penetration due to its high molecular weight and high lipophilicity, had its follicular uptake increased with the selective deposition of the $150 \mathrm{~nm}$-nanoparticles compared to a non-colloidal vehicle. Moreover, this PLA nanoparticle showed a homogeneous deposition throughout the entire follicular duct. ${ }^{55}$

\section{Metallic Nanoparticles}

Metallic nanoparticles are produced using iron, gold, silver, titanium dioxide, zinc oxide, or iron oxide, in which the drug can be both entrapped into the nucleus or adsorbed on the nanoparticle surface. ${ }^{53}$

Minoxidil was incorporated in iron oxide nanoparticles of 150-200 nm and applied in vivo on mice skin. The increase in capillary density reached $800 \%$ when the skin was pretreated with microneedling before the application of the nanoparticles, followed by the use of an external magnetic field, compared to mice that received no treatment. ${ }^{53}$ Iron oxide nanoparticles of $123 \mathrm{~nm}$ were also evaluated to entrap finasteride or dutasteride. In that study, iron oxide nanoparticles were in the form of maghemite core coated with lauric acid. The combination of lauric acid and iron was chosen because they both act on follicular metabolism. ${ }^{46}$ After the treatment, the distribution of nanoparticles on the skin varied according to the loaded molecule, ie, $3.1 \pm 0.3 \% / \mathrm{cm}^{2}$ for blank nanoparticles, $3.7 \pm 0.8 \% / \mathrm{cm}^{2}$ for finasteride nanoparticles, and 9.1 $\pm 1.0 \% / \mathrm{cm}^{2}$ for dutasteride nanoparticles. ${ }^{46}$ In this case, the slower release of the most lipophilic drug dutasteride from the nanoparticles may have increased the interaction of the nanosystem with the lipid lamellae that fill the intercellular space between the corneocytes in the stratum corneum, while the presence of finasteride made it difficult the interaction of the nanosystem with the skin. Moreover, the visible dark coloring of these particles promotes a "hair-filling" effect just after the formulation application in the skin, readily help to disguise the scarce hair areas of 
the scalp, ${ }^{46}$ which could be an additional commercial appeal for the topical use of such nanoparticles.

\section{Other Technological Approaches Energetic Physical Methods}

Some studies have proposed iontophoresis and ultrasound as energetic drug delivery methods to favor topical therapy of alopecia. Iontophoresis is a non-invasive technique that applies a small electric current (of no more than $0.5 \mathrm{~mA}$ / $\mathrm{cm}^{2}$ ) on the skin's surface to increase and control drug delivery. The technique is widely studied to stimulate the skin penetration and permeation of hydrophilic drugs, which would not be absorbed by the skin when passively applied. ${ }^{85-88}$ The transport of drugs through the skin as a result of the electric current is driven by two different mechanisms, ie, electromigration in the case of charged drugs and electroosmosis in the case of neutral drugs. The rationale of using this technique to target the drug delivery to the hair follicles is these structures are the preferred route for the electrical current passage through the skin, as they are true shortcuts that form ion channels. ${ }^{87}$

This strategy was particularly beneficial for minoxidil sulfate, the active metabolite of minoxidil, which shows unresponsiveness of topical treatment due to its high hydrophilicity and low potential to penetrate the skin. Iontophoresis was applied in gel formulations at $\mathrm{pH} 3.5$ and $\mathrm{pH} 5.5$, showing an accumulation of the drug in the follicular infundibula from 120 to $600 \mathrm{ng}$ per follicle, which represents increases of 2.3- and 4.3-fold times, respectively, compared to the passive use of the drug. ${ }^{85}$ Combination of iontophoresis and microencapsulation was also evaluated using chitosan microparticles loading minoxidil sulfate. Results showed both techniques act synergistically to enhance drug into the hair follicles, where microencapsulation of minoxidil resulted in a 6-fold increase in follicular drug accumulation compared with free-drug control, whereas the application of iontophoresis enhanced up to 8 -fold the follicular uptake of the drug. ${ }^{89}$

Sonophoresis, which consists of using ultrasound waves of low frequency to enhance transdermal drug delivery, has also been proposed for drugs involved in alopecia's topical treatment. The mechanisms by which the technique increases drug penetration are (a) the application of sound waves to the skin increases the temperature of the skin, making it more permeable ${ }^{90}$; (b) the acoustic cavitation creates bubbles that generate pores that could allow permeation of large molecular weight drugs $^{88,90}$; (c) ultrasound enhances the fluidity of lipids and permeation through transcellular pathway ${ }^{88}$; and (d) sonophoresis stimulates some disaggregation of the stratum corneum and promoting convective movements within the epidermis. ${ }^{91}$ It is important to note that this technique enables the cutaneous penetration of drugs indiscriminately without promoting any type of targeting of drug deposition into the hair follicles. In this way, the efficacy of sonophoresis $(25 \mathrm{kHz})$ for treating 30 patients affected by alopecia areata was verified using methylprednisolone or cyclosporine solutions. After 3-month treatment, sonophoresis increased the drugs' penetration, where $57 \%$ of the patients showed a partial regrowth and $29 \%$ total regrowth using methylprednisolone; and with cyclosporine, $33 \%$ of the patients had partial regrowth and $34 \%$, full regrowth. ${ }^{91}$

\section{Mechanical Methods}

Among the mechanical methods already studied to stimulate the cutaneous penetration of anti-alopecia drugs is worth mentioning the microneedling and effervescent reaction on the skin.

The technological approach of using microneedles is widely used in dermatological conditions, including alopecias, as a strategy to enhance the delivery of the drug through topical route using the conventional drug products available in the market. ${ }^{31,92,93}$ It is a minimally invasive and painless procedure in which fine needles are rolled over the skin to perforate the stratum corneum. This procedure induces collagen formation, neovascularization, and growth factor production of treated areas, increasing hair growth and facilitating penetration of first-line medications. ${ }^{93}$

The combined use of microneedling with minoxidil lotion was tested for 12 weeks in men affected by mild to moderate androgenic alopecia. A hundred cases were divided into two groups, the treatment group (microneedling with twice daily $5 \%$ minoxidil lotion) and the control group (5\% minoxidil lotion alone). Hair counts in the treatment group were 91.4 vs 22.2 follicles $/ \mathrm{cm}^{2}$ in the control group; 40 patients in the treatment group had +2 to +3 response on the 7-point visual analog scale, while none showed the same response in the control group; and in the treatment group, $82 \%$ patients reported more than $50 \%$ improvement versus only $4.5 \%$ patients in the control group. $^{94}$

Patients with androgenic alopecia and telogen effluvium were treated with the topical formulation minoxidil 
with microneedling. Fifty patients, 36 females, and 14 males, were treated over s6 months. All of them showed an enhanced frontal and vertex median density over time, respectively, of $37 \%$ and $35 \%$. The measurements of the medium hair diameter in the frontal and vertex area increased after 6 months, with a gain of $10 \%$ in the front and $9 \%$ at the vertex. Thus, the microneedling was effective in accelerating hair regrowth and hair diameter. ${ }^{95}$

The use of effervescent granules to be applied to the scalp was tested as a strategy to improve the permeation of minoxidil sulfate. ${ }^{96}$ This formulation, when deposited on the skin and moistened, triggers the formation of bubbles resulting from the reaction between an organic acid and an alkali salt, ${ }^{96,97}$ increasing the mobility in situ of the minoxidil particles and leading to an accumulation of the product in the cutaneous appendages. ${ }^{96}$ In fact, the effervescent formulation demonstrated a 2.7 -fold increase drug accumulation into hair follicles after $6 \mathrm{~h}$ of treatment compared to the control in permeation studies using porcine skin. Moreover, the solid particles dispersed in the skin created saturation points of the drug that boosted its permeation; hence, an increase of 4-fold in the epidermis was achieved, compared to the control. ${ }^{96}$

\section{Conclusion and Perspectives}

Despite the still limited quantity of drugs approved by the FDA for the treatment of various types of alopecia, the number of topical formulations available in the market for this type of treatment is large and some inconveniences arise. Most of these inconveniences are related to the low responsiveness of some patients to some topical treatments, the occurrence of skin irritation with frequent use of the formulations, as well as the reduced effectiveness because of low drug penetration into the skin. In response to the high demand of the pharmaceutical market for more effective and safer topical formulations, intense research effort has been employed in developing nanostructured systems and the application of various techniques to improve the topical therapy of the different types of alopecia.

Nanostructured systems stand out for increasing the effectiveness of the treatment and decreasing the adverse reactions related to the systemic absorption of these drugs because they tend to control release and reduce the depth of drug penetration. They generally drive the drug delivery to the target site, which is the hair follicles, and prolong the effect. These systems also allow the formation of aqueous colloids, eliminating the use of organic solvents that often irritate the skin, favoring the patient's adherence to the treatment.
Another critical point is the incorporation of intensifiers methods, such as iontophoresis, microneedling, sonophoresis, and effervescent formulations, to increase the drug's penetration and improve the therapeutic effect. Iontophoresis and sonophoresis would be more suitable for application in specialized clinics, while the use of microneedles and the addition of effervescent agents in formulations to be hydrated at the time of use are approaches that can be used in the home environment.

Most of the formulation proposals were produced on a bench-scale and tested only by in vitro laboratory assays or preclinical studies in animals. This points to the need for more investment in clinical studies to determine both the effectiveness and safety of the nanosystems and therapeutic modalities for the treatment of hair loss.

\section{Acknowledgment}

The authors would like to thank Mr. Renato Fernandes Feitosa for his assistance with the figures' design.

\section{Funding}

The authors acknowledge CNPq (Conselho Nacional de Desenvolvimento Científico e Tecnológico, Proc. \# 303066/2018-0) and University of Brasilia (Edital DPI/ UnB 03/2020) for funding their research.

\section{Disclosure}

Prof. Dr. Renata Lopez report grants from FAPESP, outside the submitted work. The authors report no other conflicts of interest in this work.

\section{References}

1. Lin J, Saknite I, Valdebran M, et al. Feature characterization of scarring and non-scarring types of alopecia by multiphoton microscopy. Lasers Surg Med. 2019;51(1):95-103. doi:10.1002/ $1 \mathrm{sm} .23017$

2. Salim S, Kamalasanan K. Controlled drug delivery for alopecia: a review. J Control Release. 2020;325:84-99. doi:10.1016/j.jconrel.20 20.06.019

3. Bolduc C, Sperling LC, Shapiro J. Primary cicatricial alopecia: lymphocytic primary cicatricial alopecias, including chronic cutaneous lupus erythematosus, lichen planopilaris, frontal fibrosing alopecia, and Graham-Little syndrome. $J$ Am Acad Dermatol. 2016;75 (6):1081-1099.

4. Phillips TG, Slomiany WP, Allison R. Hair loss: common causes and treatment. Am Fam Physician. 2017;96(6):371-378.

5. Stefanato CM. Histopathology of alopecia: a clinicopathological approach to diagnosis. Histopathology. 2010;56(1):24-38. doi:10.11 11/j.1365-2559.2009.03439.x

6. Lolli F, Pallotti F, Rossi A, et al. Androgenetic alopecia: a review. Endocrine. 2017;57(1):9-17. doi:10.1007/s12020-017-1280-y 
7. De Lacharrière $\mathrm{O}$, Deloche $\mathrm{C}$, Misciali $\mathrm{C}$, et al. Hair diameter diversity: a clinical sign reflecting the follicle miniaturization. Arch Dermatol. 2001;137(5):641-646.

8. Katzer T, Leite Junior A, Beck R, da Silva C. Physiopathology and current treatments of androgenetic alopecia: going beyond androgens and anti-androgens. Dermatol Ther. 2019;32(5):1-10. doi:10.1111/ dth. 13059

9. Pratt $\mathrm{CH}$, King LE, Messenger AG, Christiano AM, Sundberg JP. Alopecia areata. Nat Rev Dis Primers. 2017;3. doi:10.1038/ nrdp. 2017.11

10. Trüeb RM, Dias MFRG. Alopecia Areata: a comprehensive review of pathogenesis and management. Clin Rev Allergy Immunol. 2018;54 (1):68-87. doi:10.1007/s12016-017-8620-9

11. Kanti V, Röwert-Huber J, Vogt A, Blume-Peytavi U. Cicatricial alopecia. J Ger Soc Dermatol. 2018;16(4):435-461.

12. Williams DM. Clinical pharmacology of corticosteroids. Respir Care. 2018;63(6):655-670. doi:10.4187/respcare.06314

13. Jessop S, Whitelaw DA, Grainge MJ, Jayasekera P. Drugs for discoid lupus erythematosus. Cochrane Database Syst Rev. 2017;2017(5).

14. Garza-Mayers AC, McClurkin M, Smith GP. Review of treatment for discoid lupus erythematosus. Dermatol Ther. 2016;29(4):274-283. doi:10.1111/dth. 12358

15. Errichetti E, Figini M, Croatto M, Stinco G. Therapeutic management of classic lichen planopilaris: a systematic review. Clin Cosmet Investig Dermatol. 2018;11:91-102. doi:10.2147/CCID.S137870

16. Dlova NC, Salkey KS, Callender VD, McMichael AJ. Central centrifugal cicatricial Alopecia: new insights and a call for action. J Investig Dermatol Symp Proc. 2017;18(2):S54-S56. doi:10.1016/j. jisp.2017.01.004

17. Flamm A, Moshiri AS, Roche F, et al. Characterization of the inflammatory features of central centrifugal cicatricial alopecia. Physiol Behav. 2020;47(6):530-534.

18. Alzolibani AA, Kang H, Otberg N, Shapiro J. Pseudopelade of Brocq. Dermatol Ther. 2008;21(4):257-263. doi:10.1111/j.15298019.2008.00207.x

19. Fanti PA, Baraldi C, Misciali C, Piraccini BM. Cicatricial alopecia. G Ital Dermatol Venereol. 2018;153(2):230-242.

20. Miguel-Gómez L, Rodrigues-Barata AR, Molina-Ruiz A, et al. Folliculitis decalvans: effectiveness of therapies and prognostic factors in a multicenter series of 60 patients with long-term follow-up. $J$ Am Acad Dermatol. 2018;79(5):878-883. doi:10.1016/j. jaad.2018.05.1240

21. Cuellar TA, Roh DS, Sampson CE. Dissecting cellulitis of the scalp: a review and case studies of surgical reconstruction. Plast Reconstr Surg Glob Open. 2020;I:1-7.

22. Thomas J, Aguh C. Approach to treatment of refractory dissecting cellulitis of the scalp: a systematic review. J Dermatolog Treat. 2019. doi:10.1080/09546634.2019.1642441

23. Ogunbiyi A. Acne keloidalis nuchae: prevalence, impact, and management challenges. Clin Cosmet Investig Dermatol. 2016;9: 483-489. doi:10.2147/CCID.S99225

24. Lee S, Lee WS. Management of alopecia areata: updates and algorithmic approach. J Dermatol. 2017;44(11):1199-1211. doi:10.1111/ 1346-8138.13933

25. Hay RJ. Tinea capitis: current status. Mycopathologia. 2017;182 (1-2):87-93. doi:10.1007/s11046-016-0058-8

26. Grant JE, Chamberlain SR. Trichotillomania. Am J Psychiatry. 2017;173(9):868-874. doi:10.1176/appi.ajp.2016.15111432

27. Asghar F, Shamim N, Farooque U, Sheikh H, Aqeel R. Telogen effluvium: a review of the literature. Cureus. 2020;12(5):1-7.

28. Kanwar AJ, Narang T. Anagen effluvium. Indian J Dermatol Venereol Leprol. 2013;79(5):604-612. doi:10.4103/03786323.116728

29. Motofei IG, Rowland DL, Baconi DL, et al. Androgenetic alopecia; drug safety and therapeutic strategies. Expert Opin Drug Saf. 2018;17 (4):407-412. doi:10.1080/14740338.2018.1430765
30. Hosking AM, Juhasz M, Atanaskova Mesinkovska N. Complementary and alternative treatments for alopecia: a comprehensive review. Skin Appendage Disord. 2018;5(2):72-89. doi:10.1159/000492035

31. Jeong WY, Kim S, Lee SY, et al. Transdermal delivery of Minoxidil using HA-PLGA nanoparticles for the treatment in alopecia. Biomater Res. 2019;23(1):1-10. doi:10.1186/s40824-019-0164-Z

32. Stoehr JR, Choi JN, Colavincenzo M, Vanderweil S. Off-label use of topical minoxidil in alopecia: a review. Am J Clin Dermatol. 2019;20 (2):237-250. doi:10.1007/s40257-018-0409-y

33. Randolph M, Tosti A. Oral minoxidil treatment for hair loss: a review of efficacy and safety. J Am Acad Dermatol. 2020;84(3):737-746. doi:10.1016/j.jaad.2020.06.1009

34. Madheswaran T, Baskaran R, Thapa RK, et al. Design and in vitro evaluation of finasteride-loaded liquid crystalline nanoparticles for topical delivery. AAPS PharmSciTech. 2013;14(1):45-52. doi:10.1208/s12249-012-9888-y

35. Olsen EA, Whiting D, Bergfeld W, et al. A multicenter, randomized, placebo-controlled, double-blind clinical trial of a novel formulation of 5\% minoxidil topical foam versus placebo in the treatment of androgenetic alopecia in men. J Am Acad Dermatol. 2007;57 (5):767-774. doi:10.1016/j.jaad.2007.04.012

36. Purdon C, Haigh J, Surber C, Smith E. Foam drug delivery in dermatology: beyond the scalp. Am J Drug Deliv. 2003;1(1):71-75. doi:10.2165/00137696-200301010-00006

37. Varothai S, Bergfeld WF. Androgenetic alopecia: an evidence-based treatment update. Am J Clin Dermatol. 2014;15(3):217-230. doi:10.1007/s40257-014-0077-5

38. Suchonwanit P, Iamsumang W, Leerunyakul K. Topical finasteride for the treatment of male androgenetic alopecia and female pattern hair loss: a review of the current literature. $J$ Dermatolog Treat. 2020;1-6. doi:10.1080/09546634.2020.1782324

39. Javadzadeh Y, Shokri J, Hallaj-Nezhadi S, Hamishehkar H, Nokhodchi A. Enhancement of percutaneous absorption of Finasteride by cosolvents, cosurfactant and surfactants. Pharm Dev Technol. 2010;15(6):619-625. doi:10.3109/10837450903397610

40. Shatalebi MA, Rafiei Y. Preparation and evaluation of minoxidil foamable emu oil emulsion. Res Pharm Sci. 2014;9(2):123-133.

41. Sharma A, Goren A, Dhurat R, et al. Tretinoin enhances minoxidil response in androgenetic alopecia patients by upregulating follicular sulfotransferase enzymes. Dermatol Ther. 2019;32(3):3-5. doi:10.11 $11 /$ dth. 12915

42. Wang W, Chen L, Huang X, Shao A. Preparation and characterization of minoxidil loaded nanostructured lipid carriers. AAPS PharmSciTech. 2017;18(2):509-516. doi:10.1208/s12249-016-0519-x

43. Lopedota A, Cutrignelli A, Denora N, et al. New ethanol and propylene glycol free gel formulations containing a minoxidil-methyl- $\beta$ cyclodextrin complex as promising tools for alopecia treatment. Drug Dev Ind Pharm. 2015;41(5):728-736. doi:10.3109/03639045.20 14.900078

44. Angelo T, Barbalho GN, Gelfuso GM, Gratieri T. Minoxidil topical treatment may be more efficient if applied on damp scalp in comparison with dry scalp. Dermatol Ther. 2016;29:330-333. doi:10.1111/ dth. 12369

45. Kumar R, Singh B, Bakshi G, Katare OP. Development of liposomal systems of finasteride for topical applications: design, characterization, and in vitro evaluation. Pharm Dev Technol. 2007;12 (6):591-601. doi:10.1080/10837450701481181

46. Afiune LAF, Ushirobira CY, Barbosa DPP, et al. Novel iron oxide nanocarriers loading finasteride or dutasteride: enhanced skin penetration for topical treatment of alopecia. Int $J$ Pharm. 2020;587:119709. doi:10.1016/j.ijpharm.2020.119709

47. Mathes C, Melero A, Conrad P, et al. Nanocarriers for optimizing the balance between interfollicular permeation and follicular uptake of topically applied clobetasol to minimize adverse effects. J Control Release. 2016;223:207-214. doi:10.1016/j.jconrel.2015.12.010 
48. Schäfer-Korting M, Mehnert W, Korting HC. Lipid nanoparticles for improved topical application of drugs for skin diseases. Adv Drug Deliv Rev. 2007;59(6):427-443. doi:10.1016/j.addr.2007.04.006

49. Patzelt A, Richter H, Knorr F, et al. Selective follicular targeting by modification of the particle sizes. J Control Release. 2011;150 (1):45-48. doi:10.1016/j.jconrel.2010.11.015

50. Matos BN, Reis TA, Gratieri T, Gelfuso GM. Chitosan nanoparticles for targeting and sustaining minoxidil sulphate delivery to hair follicles. Int J Biol Macromol. 2015;75:225-229. doi:10.1016/j. ijbiomac.2015.01.036

51. Rancan F, Afraz Z, Combadiere B, Blume-Peytavi U, Vogt A. Hair follicle targeting with nanoparticles. Nanotechnol Dermatol. 2013:95-107.

52. Lademann J, Richter H, Schanzer S, et al. Penetration and storage of particles in human skin: perspectives and safety aspects. Eur J Pharm Biopharm. 2011;77(3):465-468. doi:10.1016/j.ejpb.2010.10.015

53. Fang C-L, Aljuffali I, Li Y-C, Fang J-Y. Delivery and targeting of nanoparticles into hair follicles. Ther Deliv. 2014;5(9):991-1006. doi:10.4155/tde. 14.61

54. Desai P, Patlolla RR, Singh M. Interaction of nanoparticles and cell-penetrating peptides with skin for transdermal drug delivery. Mol Membr Biol. 2010;27(7):247-259. doi:10.3109/09687688.20 10.522203

55. Fernandes B, Matamá T, Gomes A, Cavaco-Paulo A. Cyclosporin A-loaded poly(d,1-lactide) nanoparticles: a promising tool for treating alopecia. Nanomedicine. 2020;15(15):1459-1469. doi:10.2217/nnm2020-0089

56. Angelo T, El-Sayed N, Jurisic M, et al. Effect of physical stimuli on hair follicle deposition of clobetasol-loaded lipid nanocarriers. Sci Rep. 2020;10:176-188. doi:10.1038/s41598-019-56760-w

57. Lin YK, Al-Suwayeh SA, Leu YL, Shen FM, Fang JY. Squalenecontaining nanostructured lipid carriers promote percutaneous absorption and hair follicle targeting of diphencyprone for treating alopecia areata. Pharm Res. 2013;30(2):435-446. doi:10.1007/ s11095-012-0888-0

58. Aljuffali IA, Sung CT, Shen FM, Huang CT, Fang JY. Squarticles as a lipid nanocarrier for delivering diphencyprone and minoxidil to hair follicles and human dermal papilla cells. AAPS J. 2014;16 (1):140-150. doi:10.1208/s12248-013-9550-y

59. Ushirobira CY, Afiune LAF, Pereira MN, Cunha-Filho M, Gelfuso GM, Gratieri T. Dutasteride nanocapsules for hair follicle targeting: effect of chitosan-coating and physical stimulus. Int J Biol Macromol. 2020;151:56-61. doi:10.1016/j.ijbiomac.2020.02.143

60. Roque LV, Dias IS, Cruz N, et al. Design of finasteride-loaded nanoparticles for potential treatment of alopecia. Skin Pharmacol Physiol. 2017;30(4):197-204. doi:10.1159/000475473

61. Hamishehkar H, Ghanbarzadeh S, Sepehran S, Javadzadeh Y, Adib ZM, Kouhsoltani M. Histological assessment of follicular delivery of flutamide by solid lipid nanoparticles: potential tool for the treatment of androgenic alopecia. Drug Dev Ind Pharm. 2015;42 (6):846-853. doi:10.3109/03639045.2015.1062896

62. Oliveira ACS, Oliveira PM, Cunha-Filho M, Gratieri T, Gelfuso GM. Latanoprost loaded in polymeric nanocapsules for effective topical treatment of alopecia. AAPS PharmSciTech. 2020;21:305. doi:10.1208/s12249-020-01863-1

63. Padois K, Cantiéni C, Bertholle V, Bardel C, Pirot F, Falson F. Solid lipid nanoparticles suspension versus commercial solutions for dermal delivery of minoxidil. Int J Pharm. 2011;416(1):300-304. doi:10.1016/j.ijpharm.2011.06.014

64. Balakrishnan P, Shanmugam S, Lee WS, et al. Formulation and in vitro assessment of minoxidil niosomes for enhanced skin delivery. Int $J$ Pharm. 2009;377(1-2):1-8. doi:10.1016/j. ijpharm.2009.04.020

65. Nagai N, Iwai Y, Sakamoto A, et al. Drug delivery system based on minoxidil nanoparticles promotes hair growth in C57BL/6 mice. Int J Nanomedicine. 2019;14:7921-7931. doi:10.2147/IJN.S225496
66. Fang JH, Liu CH, Hsu RS, et al. Transdermal composite microneedle composed of mesoporous iron oxide nanoraspberry and PVA for androgenetic alopecia treatment. Polymers (Basel). 2020;12:1392. doi: $10.3390 /$ polym 12061392

67. Mura S, Pirot F, Manconi M, Falson F, Fadda AM. Liposomes and niosomes as potential carriers for dermal delivery of minoxidil. J Drug Target. 2007;15(2):101-108. doi:10.1080/1061186060099 1993

68. Gomes MJ, Martins S, Ferreira D, Segundo MA, Reis S. Lipid nanoparticles for topical and transdermal application for alopecia treatment: development, physicochemical characterization, and in vitro release and penetration studies. Int J Nanomedicine. 2014;9 (1):1231-1242. doi:10.2147/IJN.S45561

69. Das L, Kaurav M, Pandey RS. Phospholipid-polymer hybrid nanoparticle-mediated transfollicular delivery of quercetin: prospective implement for the treatment of androgenic alopecia. Drug Dev Ind Pharm. 2019;45(10):1654-1663. doi:10.1080/03639045.2019.1652 635

70. Shamma RN, Aburahma MH. Follicular delivery of spironolactone via nanostructured lipid carriers for management of alopecia. Int $J$ Nanomedicine. 2014;9(1):5449-5460. doi:10.2147/IJN. S73010

71. Zhang J, Tang H, Liu Z, Chen B. Effects of major parameters of nanoparticles on their physical and chemical properties and recent application of nanodrug delivery system in targeted chemotherapy. Int J Nanomedicine. 2017;12:8483-8493. doi:10.2147/IJN.S148359

72. Bartczak D, Muskens OL, Nitti S, Sanchez-Elsner T, Millar TM, Kanaras AG. Interactions of human endothelial cells with gold nanoparticles of different morphologies. Small. 2012;8(1):122-130. doi:10.1002/smll.201101422

73. Zhai Y, Zhai G. Advances in lipid-based colloid systems as drug carrier for topic delivery. J Control Release. 2014;193:90-99. doi:10.1016/j.jconrel.2014.05.054

74. Tolentino S, Pereira MN, Cunha-Filho M, Gratieri T, Gelfuso GM. Targeted clindamycin delivery to pilosebaceous units by chitosan or hyaluronic acid nanoparticles for improved topical treatment of acne vulgaris. Carbohydr Polym. 2021;253:117295. doi:10.1016/j. carbpol.2020.117295

75. Cevc G. Lipid vesicles and other colloids as drug carriers on the skin. Adv Drug Deliv Rev. 2004;56(5):675-711. doi:10.1016/j. addr.2003.10.028

76. Silva AC, Santos D, Ferreira DC, Souto EB. Minoxidil-loaded nanostructured lipid carriers (NLC): characterization and rheological behaviour of topical formulations. Pharmazie. 2009;64(3):177-182.

77. Radtke M, Patzelt A, Knorr F, Lademann J, Netz RR. Ratchet effect for nanoparticle transport in hair follicles. Eur J Pharm Biopharm. 2017;116:125-130. doi:10.1016/j.ejpb.2016.10.005

78. Yazdabadi A, Sinclair R. Treatment of female pattern hair loss with the androgen receptor antagonist flutamide. Australas $J$ Dermatol. 2011;52(2):132-134. doi:10.1111/j.1440-0960.2010.00735.x

79. Rathnayake D, Sinclair R. Innovative use of spironolactone as an antiandrogen in the treatment of female pattern hair loss. Dermatol Clin. 2010;28(3):611-618. doi:10.1016/j.det.2010.03.011

80. Barbosa-Barros L, Barba C, Rodríguez G, et al. Lipid nanostructures: self-assembly and effect on skin properties. Mol Pharm. 2009;6 (4):1237-1245. doi:10.1021/mp9000734

81. Ahmed OAA, Rizq WY. Finasteride nano-transferosomal gel formula for management of androgenetic alopecia: ex vivo investigational approach. Drug Des Devel Ther. 2018;12:2259-2265. doi:10.2147/ DDDT.S171888

82. Elsabahy M, Wooley K. Design of polymeric nanoparticles for biomedical delivery applications. Chem Soc Rev. 2012;41(7):2545-2561. doi: $10.1039 / \mathrm{c} 2 \operatorname{cs} 15327 \mathrm{k}$

83. Alvarez-Román R, Naik A, Kalia YN, Guy RH, Fessi H. Skin penetration and distribution of polymeric nanoparticles. J Control Release. 2004;99:53-62. doi:10.1016/j.jconrel.2004.06.015 
84. Arif T, Dorjay K, Adil M, Sami M. Dutasteride in androgenetic alopecia: an update. Curr Clin Pharmacol. 2017;12(1). doi:10.2174/ 1574884712666170310111125

85. Gelfuso GM, Gratieri T, Delgado-Charro MB, Guy RH, Lopez RFV. Iontophoresis-targeted, follicular delivery of minoxidil sulfate for the treatment of alopecia. J Pharm Sci. 2013;101(5):1488-1494. doi:10.1002/jps

86. Wang Y, Thakur R, Fan Q, Michniak B. Transdermal iontophoresis: combination strategies to improve transdermal iontophoretic drug delivery. Eur J Pharm Biopharm. 2005;60(2):179-191. doi:10.1016/ j.ejpb.2004.12.008

87. Priya B, Rashmi T, Bozena M. Transdermal iontophoresis. Expert Opin Drug Deliv. 2006;3(1):127-138. doi:10.1517/17425247.3.1.127

88. Marwah H, Garg T, Goyal AK, Rath G. Permeation enhancer strategies in transdermal drug delivery. Drug Deliv. 2016;23(2):564-578. doi:10.3109/10717544.2014.935532

89. Gelfuso GM, de Barros MAO, Delgado-Charro MB, Guy RH, Lopez RFV. Iontophoresis of minoxidil sulphate loaded microparticles, a strategy for follicular drug targeting? Colloids Surf $B$ Biointerfaces. 2015;134:408-412. doi:10.1016/j.colsurfb.2015. 07.031

90. Park D, Park H, Seo J, Lee S. Sonophoresis in transdermal drug deliverys. Ultrasonics. 2014;54(1):56-65. doi:10.1016/j.ultras.2013. 07.007
91. Santoianni P, Nino M, Calabro G. Intradermal drug delivery by low frequency sonophoresis $(25 \mathrm{KHz})$. Dermatol Online J. 2004;10 (2):7-10.

92. Waghule T, Singhvi G, Dubey SK, et al. Microneedles: a smart approach and increasing potential for transdermal drug delivery system. Biomed Pharmacother. 2019;109:1249-1258. doi:10.1016/j. biopha.2018.10.078

93. Fertig RM, Gamret AC, Cervantes J, Tosti A. Microneedling for the treatment of hair loss? J Eur Acad Dermatol Venereol. 2018;32:564-569. doi:10.1111/jdv.14722

94. Dhurat R, Sukesh M, Avhad G, Dandale A, Pal A, Pund P. A randomized evaluator blinded study of effect of microneedling in androgenetic alopecia: a pilot study. Int J Trichology. 2013;5(1):6-11. doi:10.4103/0974-7753.114700

95. Starace M, Alessandrini A, Brandi N, Piraccini BM. Preliminary results of the use of scalp microneedling in different types of alopecia. J Cosmet Dermatol. 2019;19:646-650. doi:10.1111/ jocd.13061

96. Pereira MN, Schulte HL, Duarte N, et al. Solid effervescent formulations as new approach for topical minoxidil delivery. Eur J Pharm Sci. 2017;96:411-419. doi:10.1016/j.ejps.2016.10.016

97. Ipci K, Oktemer T, Birdane L, et al. Effervescent tablets: a safe and practical delivery system for drug administration. ENT Updat. 2016:46-50. doi:10.2399/jmu.2016001009

\section{Publish your work in this journal}

Clinical, Cosmetic and Investigational Dermatology is an international, peer-reviewed, open access, online journal that focuses on the latest clinical and experimental research in all aspects of skin disease and cosmetic interventions. This journal is indexed on CAS.
The manuscript management system is completely online and includes a very quick and fair peer-review system, which is all easy to use. Visit http://www.dovepress.com/testimonials.php to read real quotes from published authors. 